\title{
How Well Do Catholic and Other Faith-based Schools Serve the Poor? A Study with Special Reference to Africa: Part II: Learning
}

\author{
Quentin Wodon* \\ Lead Economist, Education Global Practice, The World Bank, Washington, USA
}

\begin{abstract}
This paper ${ }^{1}$ is the second in a set of two on the extent to which Catholic and other faith-based schools are serving the poor well. Catholic and other faith-based schools reach millions of children who live in poverty, yet this does not necessarily mean that they are serving these children well enough. The paper considers two separate issues. First, beyond academic subjects, Catholic and other faith-based schools emphasize learning related to values and religion. Do they succeed in doing so? Based on small sample survey data and qualitative fieldwork, as well as broader data on parental satisfaction with schools, the paper provides a tentative and mostly positive answer to this question, at least from the view of parents. The second issue is where performance is weaker. Education systems are affected by a learning crisis in the developing world. All schools should ensure that students learn, but too often this is not the case. The second part of the paper documents this learning crisis and the fact that Catholic and other faith-based schools are not immune to it. This is done in part through a rapid review of the recent World Development Report on education's promise, and a companion piece for sub-Saharan Africa. Estimates of performance for selected African countries are also provided. The results are sobering: too many children are not learning while in school. Finally, the paper briefly summarizes evidence from the literature on interventions that could improve learning, including in Catholic and faith-based schools.
\end{abstract}

Keywords: Catholic schools, faith-based schools, Africa, religious education, school performance, forms of learning. 


\section{Introduction}

Catholic and other faith-based schools are an essential component of national education systems. Globally, estimates from the Church's statistical yearbook suggest that 35 million children were enrolled in Catholic primary schools in 2016, with an additional 20 million children in Catholic secondary schools (Secretaria Status, 2018; Wodon, 2019a). The schools often profess to serve the poor, and this is a core part of their mission (see for example Congregation for Catholic Education, 1977, for Catholic schools). Yet the extent to which the schools manage to do so is open to question. This paper is the second in a set of two providing a rapid assessment of how well Catholic and other faith-based schools serve the poor ${ }^{2}$.

The first paper on schooling provided evidence that while Catholic and other faith-based schools reach many poor children, especially in low income and lower-middle income countries, they nevertheless tend to serve the poor less than better off households, especially at the secondary level (Wodon, 2019b). This is in part because Catholic and other faith-based schools in many countries do not receive much support from the state, leading to higher out-of-pocket costs for parents. As a result, Catholic and other faith-based schools are less affordable for the poor. Despite such constraints, it is clear that the schools manage to reach millions of children who live in poverty.

Does this mean that they serve these children well? Not necessarily. Even when children from underprivileged backgrounds enroll in Catholic and other faith-based schools, it does not mean that they are learning enough while in school. In primary schools for example, learning enough means mastering foundational cognitive skills such as basic literacy and numeracy that are important for students to be able to become lifelong learners and succeed professionally. National and international assessment data suggest that many education systems are failing to achieve high proficiency rates among students, especially in developing countries (World Bank, 2018).

It is often stated that students in Catholic and other faith-based schools perform better than students in other schools. When relying on simple statistical comparisons, this is often the case. But to assess whether Catholic and other faith-based schools perform better, the analysis must control for differences in the characteristics of children enrolling in different types of school. Some studies that incorporated such controls have suggested an advantage for Catholic schools (see for example Evans et al., 1995; Altonji et al. 2005), but this has not always been the case (e.g., Jepsen, 2003; Elder and Jepsen, 2014). Most of these studies were implemented in the United States. The evidence is weaker in developing countries. In my own limited work on Colombia (Parra-Osorio and Wodon, 2014), Cameroon 
(Backiny-Yetna and Wodon, 2009a), the Democratic Republic of Congo (Backiny-Yetna and Wodon, 2009b), Sierra Leone (Wodon and Ying, 2009) and West and Central Africa (Nayihouba and Wodon, 2018), the advantage enjoyed by Catholic and other faith-based schools after controlling for student characteristics was limited. This makes sense given that many of these schools have limited resources at their disposal. In addition, these studies were based on regression or matching techniques, and not experimental methods, so that the results should be treated with some caution and as tentative only ${ }^{3}$. Apart from cognitive skills, education systems try to impart other types of knowledge and skills to students, including socioemotional skills that are crucial for success in life. These skills relate to attitudes and values that people need at work and in their personal life. While cognitive skills emphasize the mastery of subject-specific knowledge, socio-emotional skills are valuable across subject areas as they relate to how we behave, including how we motivate ourselves and how we interact with others. While comparable data across counties on socio-emotional skills across countries are not yet widely available, it is unlikely that education systems are performing well in this area either, even if there is limited evidence that Catholic and other faith-based schools may provide value by contributing to stronger communities (Brinig and Garnett, 2015) and higher levels of civic participation (Dee, 2005) ${ }^{4}$.

Finally, learning related to religion and faith, and how faith interacts with both socio-emotional and cognitive skills, is also crucial not only for Catholic schools, but also for other faith-based schools. For Islamic schools or madrasas (madrasa means a school in Arabic), there may be a perception that the focus of instruction is primarily on religious studies. This may be the case for some types of madrasas in some countries, especially at the post-primary level, but it is generally not true. From the ninth century onwards, apart from religious knowledge, madrasas taught other forms of knowledge, including scientific knowledge. They trained generations of Islamic leaders and scholars, but also civil servants who held positions in government (Hallaq, 2009). Today, madrasas continue this tradition. In Ghana for example, Boyle et al. (2007) identify four types of Islamic schools: Qur'anic schools that focus on religious instruction and memorization of the Qur'an typically after normal school hours; Arabic schools that provide instruction in Arabic in secular subjects apart from religious studies; Arabic English schools that offer the government curriculum plus Arabic language and religious studies; and Islamic schools under the management of, and with funding from, the government. Clearly, while the various types of madrasas in Ghana set for themselves different missions, most schools offer a combination of religious and secular topics, as is the case for Catholic and Christian schools. 
As is the case for madrasas, Christian schools also have a long history in the developing world where some of the first schools were founded by missionaries. Today, at least according to foundational texts, their primary objective is still often defined as the formation of good Christian people, as is the case for Catholic schools (Congregation for Catholic Education, 1977). Yet in practice, the focus is again broader, especially since the schools have large non-Catholic populations enrolled. Defining the specific characteristics of a faith-based schools and how this should affect what the school does is not always obvious. For Catholic schools, in an interesting essay, Delfra et al. (2018) suggest four characteristics of education "in a Catholic key": it is based on a personal encounter with others who pass on faith and wisdom; it is sacramental, permeated by an intentional culture; it is Eucharistic by affirming the communal nature of the person; and it is unitive, combining faith and reason. Such an education may create an environment that fosters excellence, whereby children of different faiths and at different stages in their own journey can strive together not only academically, but also spiritually, thereby promoting the fullness of human flourishing. Many of these themes are also emphasized by the Congregation for Catholic Education (2017) in its call for an education that leads to fraternal humanism and a "civilization of love". This is not simply an aspiration: it is often practiced thanks to the vocational commitment and spiritual capital embedded among teachers and staff (Grace, 2002a, 2002b).

Given the emphasis placed by Catholic and other faith-based schools on faith and values, it should not be surprising that the parents who choose those schools for their children may have on average different priorities than parents sending their children to public or private secular schools. To document how this is indeed the case, part of the analysis for this paper is based on small sample survey data and qualitative fieldwork conducted in two African countries, Burkina Faso and Ghana. Building on previous work by the author (Wodon, 2014, 2015), the focus is on the reasons that lead parents to choose different types of schools, and how this affects their assessment of the schools. This analysis is then complemented by data for a larger number of counties on the comparative performance of schools according to indicators of parental satisfaction with the education provided by the schools. The aim of the analysis is to expand the assessment of whether Catholic and other faith-based schools are successful in serving the poor beyond a sole focus on results from traditional student assessments.

The data suggest that faith-based schools often have parental satisfaction rates that are higher than public schools, and that parents value the focus on religious instruction and values that is provide by faith-based schools. Yet again, as mentioned earlier, this does not mean that catholic and other faithbased schools are doing well. The schools must still ensure that students learn and acquire the 
foundational cognitive skills that they will need in adulthood. Unfortunately, this is often not the case, especially in the developing world. Because levels of learning are so low in many countries, even if Catholic and other faith-based schools were to provide a better education than other types of schools, this would probably still not be sufficient to ensure learning for all. As pointed out in the recent World Development Report on realizing education's promise, developing countries are faced with a massive learning crisis (World Bank, 2018). In low income counties, and especially in sub-Saharan Africa, this crisis is especially severe (Bashir et al., 2018). This learning crisis is likely to affect Catholic and other faith-based schools in much the same way that it affects public and private secular schools. The second part of the paper discusses those issues, and what schools could do to improve performance.

Finally, the last part of the paper briefly summarizes some of the evidence from the literature on interventions that could improve learning. There is no way to be comprehensive in this review, since this literature is so large. But a few pointers can be provided based on the results of experimental or quasi experimental studies. This is done for both pedagogical interventions and broader reforms.

\section{Distinctiveness of Catholic and Other Faith-based Schools}

This section considers some of the unique features of Catholic and other faith-based schools from the point of view of parents. Recognizing that the schools can only thrive if parents choose the schools to educate their children, the analysis relies on survey data to document the level of satisfaction of parents with the schools, and the reasons why they chose the schools. The analysis makes it clear that the schools serve a unique purpose not provided by other schools (and which has been at times resisted by governments; see the historical case study for Ghana by Olivier and Wodon, 2014 as an example). In that sense, it seems fair to say that the schools provide a highly valuable service to their communities.

\subsection{Parental Satisfaction with Schools}

Catholic and other faith-based schools can thrive only to the extent that parents choose these schools to educate their children. While in some countries faith-based schools are struggling, in many countries they are expanding their networks. Enrolling children in faith-based schools often requires sacrifices from parents since the schools receive only limited or no support from governments. This forces the schools to recover operating costs through fees, thus raising out-of-pocket costs of households. Yet many parents accept to pay these higher costs because they believe that the schools provide them with a service not provided in the same way by public and private secular schools. 
Parental satisfaction with faith-based schools tends to be high. As done in the companion paper on schooling for enrollment rates (Wodon, 2019b), nationally representative household surveys can be used to measure parental satisfaction with schools. This type of analysis was conducted for public, private secular, and faith-based schools in sub-Saharan Africa was conducted by Wodon (2014). In most cases Catholic schools are not identified separately from other faith-based schools in most survey questionnaires, so Catholic schools are simply considered as part of faith-based schools. Estimates are based on data for seven West and Central African countries: Burkina Faso, Burundi, Ghana, Niger, Mali, Republic of Congo, Senegal. Comparative estimates of satisfaction rates are provided in Table 1.

Despite low levels of learning in many schools as will be discussed later, and possibly due to low expectations, six in ten parents declare being satisfied with the quality of the education provided by schools. However, average satisfaction rates are substantially higher for faith-based schools than public schools. For primary schools, 72.8 percent of parents with children in faith-based schools are satisfied with the schools, versus 56.8 percent for parents with children in public schools. Similarly, for secondary schools, 75.6 percent of parents with children in faith-based schools are satisfied with the schools, versus 60.8 percent for parents with children in public schools. Table 1 also shows that satisfaction with faith-based schools is slightly lower than for private secular schools, probably because private secular schools charge substantially higher fees and may therefore provide better services in some areas.

While the fact that faith-based schools have higher satisfaction rates than public schools is encouraging, from the point of view of the services provided to the poor, much remains to be done. Satisfaction rates are however not uniform across socio-economic groups. Table 1 also provides data on satisfaction rates by quintiles of well-being using data on consumption per capita or per equivalent adult. The first quintile represents the poorest 20 percent of households, while the fifth quintile represents the richest 20 percent of households. Satisfaction rates are much lower in the bottom quintiles, presumably because the quality of the schools that these households must rely on is lower, and among the very poor, faith-based schools do not necessarily do better than public schools. This suggests that there is heterogeneity among faith-based schools to the detriment of the poor. This heterogeneity is also observed for private secular schools, but less so for public schools.

$<$ Table 1 here $>$ 
The advantage of using nationally representative household survey when looking at satisfaction with schools is that the data are representative of entire nations. The disadvantage is that few questions are asked in the surveys about parental satisfaction with schools, and typically no questions are asked about why parents send their children to specific schools. To explore these questions further, insights can be obtained from small sample surveys and qualitative interviews. Such data were collected in 2010 in Burkina Faso and Ghana in one rural area and one urban area for each country (Gemignani et al., 2014). A condition for selection of the areas was that public and faith-based schools had to be available, with ideally also private secular schools in the area. Within faith-based schools, both Christian and Islamic schools had to operate so that parental preferences and satisfaction could be compared not only between public and faith-based schools, but also by faith affiliation. Based on those data, parental preferences are discussed in the next section, but the data was also used to assess satisfaction rates.

While sample sizes were small, and the results were only representative of the areas surveyed, they were instructive. In Ghana, most parents appeared to be dissatisfied with the resources available in public schools. By contrast, two thirds of parents in faith-based schools were satisfied with these resources. Differences were smaller for the assessment of academic performance in the schools, but perceptions of faith-based schools were more favorable than for public and private secular schools. In Burkina Faso, satisfaction rates were also high for faith-based schools, especially for parents sending their children to Christian schools. Public schools ranked lower. However, in terms of the quality of the relationships between the schools and their community, Islamic schools had the highest ratings. In all schools, parents suggested that improvements could be made, among others to reduce crowding, especially in public schools with about half of the parents citing this problem. In Islamic schools, two in four parents said that the level of the school fees was beyond their means, and some parents complained about uneven academic performance and a lack of trained teachers. Yet as discussed in the next section, while all parents value academic performance, there are differences between schools.

\subsection{School Choice}

Why do parents send their children to various types of schools? A key purpose of the data collection for Burkina Faso and Ghana was to answer that question. The education provided by faithbased schools was valued by parents and communities for reasons related to both perceived quality and the promotion of religious and moral values. But there were also differences between Franco-Arab or Islamic schools and Christian schools. As shown in Table 2, parents at Christian schools in Burkina Faso 
said that they chose their school for its academic and teacher quality (76.7 percent and 46.7 percent, respectively). By contrast, respondents in Islamic schools emphasized the opportunity for their children to receive a religious education (83.9 percent), with smaller numbers listing academic or teacher quality as factors for the choice of the school (25.8 percent and 12.9 percent, respectively). In public schools, location was a deciding factor for more than two thirds (70 percent) of parents, followed by academic quality (46.7 percent) and the lack of school fees (30.0 percent). Education on moral values was listed as a reason for school choice by about a third of parents in Islamic and Christian schools, but by no parents in public schools. Results for Ghana are similar to those obtained for Burkina Faso. Religious knowledge was the main factor leading to the choice of an Islamic school. It also mattered for Christian school, but slightly less so, while the importance of academic performance and teacher quality mattered more than was the case for Islamic schools. For public schools, low cost and proximity were the driving factors.

$<$ Table 2 here $>$

Several other questions were asked to parents to better understand why they chose a specific school for their children. One such question was about the most important area of study for their children. For children in Franco-Arab and Islamic schools, religious education came first, followed by moral education and academics (in this case, literacy). For parents at Christian schools, academics came first, as it did for parents at public schools. Parents were also asked to choose the educational goal of highest importance among social, moral, academic and spiritual goals. Many parents in Islamic schools selected spiritual goals and the betterment of society as the most important educational goals, but fewer parents at Christian did so, as they emphasized moral values more. In public schools, the role of religious and moral education came less often in answers provided by parents. It is also worth noting that Christian schools are attended by children of all faiths, and religious education is not emphasized in a major way the curriculum. Rather, the schools stress moral values in addition to secular subjects. By contrast, religious education features more prominently in the curriculum of Franco-Arab and Islamic schools, and those schools are attended almost entirely by Muslim children, with a few exceptions.

What can be concluded from this analysis? Beyond academic subjects, Catholic and other faithbased schools emphasize learning related to values and religion. Do they succeed in doing so? Based on the small sample survey data and qualitative fieldwork carried in Ghana and Burkina Faso, as well as the comparative data on parental satisfaction with schools presented in the previous section, the analysis 
suggests a tentative and mostly positive answer to this question, at least from the view of parents. This does not mean that students are learning all that they should in these areas, but at least parents recognize the value provided to them by Catholic and other faith-based schools. In the next section, the focus shifts on how well schools are doing on more traditional measures of student performance.

\section{Academic Performance}

Catholic and faith-based schools respond to parental demand in providing an education for their children that places a higher emphasis on faith and values than in other schools. But they must also provide foundational skills such as basic literacy and numeracy at the primary level, so that children have the knowledge needed to succeed in secondary school and beyond, and continue to learn as adults. These skills must be imparted by Catholic and faith-based and public schools alike. Too often, this is not the case, as documented in this section. Findings from the World Development Report 2018 on the learning crisis in many countries are first summarized. To complement this brief review of the findings of the World Development Report, a brief discussion of findings from a companion study to the report for sub-Saharan Africa by Bashir et al. (2018) is also provided. The results from both studies are sobering: many students are not learning enough while in school, and this is also likely to be the case for Catholic and faith-based schools even if they may be performing slightly better than public schools.

\subsection{World Development Report}

Once a year, the World Bank publishes its flagship World Development Report, with a different but important topic chosen every year. For the first time in the 31-year history of the report, the 2018

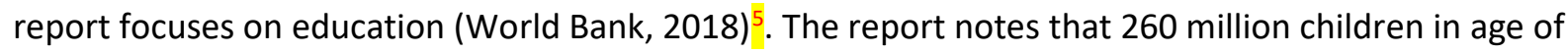
schooling are not in primary or secondary school. This is due among others to fragility and conflict, but also to discrimination (as is the case for indigenous peoples or girls confronted with oppressive social norms) and other obstacles. For example, children with disabilities are much less likely to go to school, and are falling behind as progress is achieved by other children. Yet, while the report acknowledges that much remains to be done to provide access to schools for all children, its focus is squarely on the learning crisis faced by education systems in much of the developing world. The report's core message is that schooling does not necessarily lead to learning, as too many children fail to achieve proficiency in the materials being taught in school. This is a wasted opportunity with severe consequences in adulthood, but it is not inevitable since policies can improve student learning. 
At first glance, the report does not appear to have much to offer in terms of new thinking or analysis of the role played by Catholic and other faith-based schools, or more generally private schools, as well as the particular challenges faced by these schools. In its 216 pages of dense material, the report mentions the word "faith" twice, once with reference to the faith that parents and students have in the power of education, and once with reference to the possibility that quality education could restore faith in government and society. The words "religion" or "religious" are together mentioned ten times, more often than not in a rapid succession of words stitched together to mention multiple dimensions or student characteristics that may affect educational outcomes, such as income, disability, age, gender language, or ethnicity. Analysis by faith affiliation or by denomination within broad faith affiliations is absent. The role that various schools play in imparting values among students is briefly recognized, but not really explored. Even the broader and complex debate on the potential role of the private sector in the provision of education is not discussed much, with the exception of a box in the chapter exploring why education systems are often misaligned with the goal of learning for all. These omissions are not necessarily drawbacks: they simply reflect choices made by the team preparing the report to focus for the most part on traditional measures of learning, with a focus on foundational skills and an analysis of how the low performance of many education systems could potentially be improved.

And yet, there is much to learn from the report for Catholic and other faith-based schools, and for private schools more generally. The diagnostic of the learning crisis and the recommendations provided by the report are relevant for Catholic and other faith-based schools. As summarized on the World Development Report's website ${ }^{6}$, the learning crisis faced by many education systems is analyzed in the report in three ways. First, using national and international student assessment data, the report demonstrate that many students are not learning, or not learning enough. For example, three in four third grade students in East African countries such as Kenya, Tanzania, and Uganda do not understand a very simple sentence. In rural India, three-quarters of students in the same grade are not able to solve a simple two-digit subtraction. Even in countries that perform better, such as Brazil, the gaps with the performance of students in high income countries are enormous. Furthermore, at current rates of improvement, decades or even hundreds of years would be needed for students in developing countries to be able to catch up with students in high income countries.

Because there is often a perception - valid or not - that Catholic and faith-based schools perform better than public schools, some may assume that the learning crisis do not apply to these schools. This would be a mistake. In low income and lower-middle income countries where student 
achievement is lowest, even if Catholic and faith-based schools were to perform slightly better than public schools, this would still lead to very low levels of performance. A striking result from the report is that an average student in a low-income country performs worse than 95 percent of students in highincome countries on basic measures of literacy and numeracy. Another striking result is that many highperforming students in middle-income countries would rank in the bottom fourth in wealthier countries. Such findings apply to students from Catholic and faith-based schools as they do to public schools.

Next, the report analyzes some of the factors leading to lack of learning. These factors are multiple, but the report emphasizes the potential role of early childhood development programs and policies. Children often arrive unprepared to learn in primary schools, in part due to a lack of adequate nutrition and stimulation in the first 1,000 days of their life. This can have dramatic consequences in adulthood. For example, studies suggest that chronic malnutrition (stunting) for children under the age of five can lead to lack of development of synapses in the brain and ultimately results in losses in productivity and earnings in adulthood of one fourth versus well-nourished children.

Once in school, students are too often taught by teachers who lack the skills necessary to teach effectively. One issue is lack of knowledge: it is common for teachers not to master the material that they are supposed to teach ${ }^{7}$. Another issue is poor pedagogy: in too many countries, classroom time is devoted to lecturing and memorization, not interactive learning and problem solving. Teacher motivation and incentives are also important issues, leading to high rates of absenteeism from school, or from the classroom when teachers are present in the school. Other inputs such as textbooks often fail to reach classrooms or affect learning. Finally, schools and education systems are often poorly managed. The lack of appropriate governance and accountability undermine the quality of the education provided.

A third point made by the report relates to the fact that beyond the factors leading to poor learning outcomes, the learning crisis has deeper systematic roots. The various stakeholders in the education system -teachers, principals, bureaucrats, politicians, the judiciary, employers, private schools, suppliers of educational inputs, international donors, and of course parents and students - all have potentially competing interest that do not align well with the goals of learning for all. Lack of appropriate incentives for the interests of the various stakeholders to align lead to poor outcomes.

\subsection{Sub-Saharan Africa Companion Study}

Several regional studies are being prepared by World Bank staff as companion pieces to the World Development Report. One of the first such studies to be completed is for sub-Saharan Africa, a 
region where the role played by Catholic and other faith-based schools is especially prominent, at least in some countries. As is the case for the World Development Report, the study by Bashir et al. (2018) is also virtually silent on the role played by faith-based schools. The word "faith" is mentioned once, but in reference to good faith for negotiations. The words "religion" and "religious" are mentioned a handful of times, in part due to a small contribution by the author of this article to the study.

The study for sub-Saharan Africa includes a limited discussion of private schools. The study notes that competition between public and private schools may have benefits, but it does not find evidence to this effect in cross-country analysis. The study quotes a review on the performance of public and private schools in low- and middle-income countries which suggests that the perception of higher quality in private schools is not supported by rigorous evidence, with the exception of indicators of the quality of teaching such as less absenteeism and more academic contact time between students and teachers (Day Ashley et al., 2014). Apart from cross-sectional analysis of assessment data for Africa such as PASEC (Programme d'analyse des systèmes éducatifs de la Confemen) and SACMEQ (Southern and Eastern Africa Consortium for Monitoring Educational Quality), the report team carried an analysis using data from PISA (Programme for International Student Assessment). The analysis suggested that most difference in scores between public and private schools was due to differences in student characteristics (Lockheed et al., 2015).

The study by Bashir et al. (2018) does not distinguish specifically Catholic and other faith-based schools from the broader universe of private schools, but the student assessment data can be used for such a disaggregation. This is done for West and Central Africa in Table 3 using data from PASEC. The analysis is based on data collected in 2014 in ten countries: Benin, Burkina Faso, Burundi, Cameroon, Chad, Cote d'Ivoire, Congo, Niger, Senegal, and Togo. The data are normalized so that on average, students have a score of 500 for both the mathematics and reading assessments. Three types of schools are compared in the Table (other types of schools such as community-based schools and other types of private schools are not included). The estimates suggest that students in faith-based schools on average have higher test scores than students in public schools, but lower scores than students in private secular schools that do not benefit from state support. Whether these differences are due to school characteristics or the characteristics of the students and their families remains to be seen, but what is clear is that given that overall, the performance of the schools is very low, even if faith-based schools were performing slightly better than public schools after controlling for the characteristics of the students that they enroll, their performance would still be low by international standards. In other 
words, faith-based as well as other schools could improve their performance, especially for children in poverty that tend to do worse than other students.

$<$ Table 3 here $>$

Finally, as was the case for the World Development Report, the study for sub-Saharan Africa by Bashir et al. (2018) notes that Ministries have limited capacity to monitor and regulate private schools beyond ensuring that minimal standards for education provision are met. The study however acknowledges that private schools may increase the availability and accessibility of school for households, especially in contexts of conflict and fragility, and provide through low-fee private schools access to low-income groups that do not have access to public schools of sufficient quality (see for example Moumne and Saudemont, 2015). In both cases, given existing gaps in coverage, leveraging the private sector to expand educational opportunities may be most important at the secondary level.

\section{Improving Student Performance}

What could be done to improve student learning in low income countries especially? While the literature on this topic is vast and cannot be summarized here in any comprehensive way, a few pointers based on a review by Evans and Popova $(2015,2016)$ summarized in Wodon $(2016)$ may help, in case some of the readers of this journal are not familiar with this literature. While this literature does not consider issues specific to the mission of Catholic and other faith-based schools, it does explore what works in improving foundational skills for students, especially at the primary level and in low income and lower-middle income countries where many Catholic and faith-based schools are located.

The authors considered six systematic literature reviews by Conn (2014), Glewwe et al. (2014), Kremer et al. (2013), Krishnaratne et al. (2013), McEwan (2014), and Murnane-Ganimian (2014) that identified hundreds of rigorous studies measuring the impact of various interventions on learning outcomes in developing countries. While there was quite a bit of divergence in the recommendations made by the various literature reviews, a few commonalities emerged as well. As suggested in Table 4, three types of interventions were recommended across multiple reviews: (1) Pedagogical interventions that match teaching to individual student learning levels; (2) Individualized, repeated teacher training associated with a specific method or task; and (3) Accountability-boosting interventions. This does not mean that other interventions cannot be successful or are not required, but these were the 
interventions for which there seemed to be a consensus about their effectiveness. Many of these interventions could be considered as incorporating a focus on the poor, because they are to a large extent designed to enable teachers to focus on those students in the classroom who have the most difficulty, and adapt both the level and mode of instruction to the needs of those students. These students are disproportionately from families living in poverty.

It is worth noting that the rationale for the third type of interventions on accountability stems from the idea that they provide a shorter route to making schools accountable to students and parents. A simple framework was proposed on ways to make service providers more accountable to the poor in the 2004 World Development Report (World Bank, 2003). Two routes towards accountability were distinguished. The short route runs directly from users (the children in school and their parents) to service providers (the schools). The long route is much more indirect because users must hold service providers accountable through the state, often with little success especially for vulnerable groups. Accountability-boosting interventions such as school-based management reforms aim to give some teeth to the short route by empowering parents and communities in the management of schools. Whether the three types of interventions hold the same promise for different types a school is a question that is beyond the scope of this paper, but all three types of interventions are worthwhile.

$<$ Table 4 here $>$

The magnitude of the gains in student performance that could be achieved is however not be the same for all interventions and sequencing does matters. Crouch and DeStefano (2015) suggest that there may be a dichotomy in the size of the gains that can be expected with various types of reforms and interventions. The impact of broad-based reforms tends to be smaller than interventions focusing on specific pedagogical practices, at least in the short term. The types of reforms that the authors have in mind are illustrated in Table 5. The authors did not conduct a systematic review to reach this conclusion, but they considered a wide range of studies. The impact of interventions focused on pedagogical practice was typically larger. This does not mean that broad-based reforms are not needed - they may be a prerequisite in order to be able to implement well more focused pedagogical reforms at scale in national education systems since teachers and schools must be accountable for those reforms to succeed as well. But it is important to note that the two types of reforms may have impacts of different orders of magnitude, and that broad-based reforms may take longer to bear fruits. 
$<$ Table 5 here $>$

More generally, the World Development Report on the learning crisis makes it clear that there is no magic bullet to improve learning, but it calls for three main areas of focus (World Bank, 2018). First, it is essential to measure learning through student assessments and to make widely available the results of these assessments. This may sound like an obvious first step to measure the quality of the education being provided, but many developing countries still do not adequately measure learning at the end of primary and lower secondary school ${ }^{8}$. Second, policy makers should rely on the available evidence on what works to improve learning. Third, the actions of the various stakeholders must be aligned to make education systems work towards improving learning. Admittedly, these three recommendations are somewhat generic - measuring performance, basing policies on proven interventions, and aligning incentives for stakeholders are recommendations that could probably be applied to many other topics or areas apart from education. These recommendations are not specific to education. But these three steps are part of a positive feedback loop that could improve education outcomes if implemented well.

Finally, what about the importance of imparting values and other types of skills to students? The World Development Report acknowledges the concern that a focus on traditional learning outcomes could detract from other objectives pursued by schools. Schools often aim to educate the whole person, for example through socioemotional and noncognitive skills. They also often emphasize values conducive to social cohesion. Is there a risk that these other objectives pursued by schools could be crowded out by a narrow focus on areas such as literacy, numeracy, and reasoning? The report's response is that the trade-off may not be as severe as feared. A focus on foundational skills could actually be beneficial for the emergence of higher order skills and values. While cognitive skills and socioemotional skills are different from each other, they may reinforce each other. While socioemotional skills are important for students to acquire cognitive skills, the reverse is also true: without cognitive skills, it is hard for schools to help students acquire the socioemotional skills they need.

\section{Conclusion}

Schooling is not the same as learning. This is the first sentence of the World Development Report on learning to realize education's promise. This statement rings true for students in all types of schools, whether faith-based or not. Too many students fail to learn to read or can't perform simple 
calculations. Many also fail to acquire adequate socio-emotional skills. Gaps in learning continue at the secondary level. Parents send their children to school so that they can learn. It is legitimate to consider the performance of Catholic and other faith-based schools on commonly accepted metrics of learning performance. But this does not exhaust the aims that Catholic and other faith-based schools are pursuing. These schools also emphasize learning related to faith and values.

For this reason, this paper started with an investigation of the unique features of Catholic and other faith-based schools, as seen from the point of view of parents. The results were broadly positive. Based on small sample survey data and qualitative fieldwork in two countries, and broader data on satisfaction rates with various types of schools in a larger set of countries, Catholic and other faith-based schools appear to provide a service that is valued by parents. There are concerns however as satisfaction rates with schools are lower among poorer households than among households who are better off.

The paper considered next school performance was measured by international assessments. The results were less encouraging. While specific data on the performance of Catholic and faith-based schools remain scarce in the developing world, the available data suggests that many schools have a long way to go to improve student performance on foundational skills, even if they may perform slightly better than public schools. As just one data point, it was noted that an average student in a low-income country performs worse than 95 percent of students in high-income countries on basic measures of literacy and numeracy ${ }^{9}$. This affects Catholic and faith-based schools as well as public schools.

How could schools, including Catholic and other faith-based schools do better? There is no easy answer, but insights are available from a growing number of interventions that have been evaluated rigorously. A key recommendation of the World Development Report on the learning crisis was that education systems should measure how well they are doing, act upon the evidence from rigorous evaluations of what works, and ensure that stakeholders are aligned towards improving learning for all. These recommendations are also valid for Catholic and other faith-based schools. 
${ }^{1}$ The paper was prepared on the author's own personal time and not as part of his duties at the World Bank. The analysis and views expressed in this paper are those of the author only and may not reflect the views of the World Bank, its Executive Director, or the countries they represent.

${ }^{2}$ At the suggestion of the journal's editor, the paper is based in part on previous work by the author at the World Bank, but it also includes new elements and a review of some of the relevant literature.

${ }^{3}$ Evaluating the impact of interventions or of Catholic schools on learning, is no easy task. Ideally, impact evaluations should be based on experimental methods such as randomized control trials, as done in the field of medicine. In practice, this is not always feasible. An alternative is to rely on quasi-experimental methods, such as certain types of regression analysis or matching techniques, but these alternatives do not always control for factors that may bias the evaluation of interventions.

${ }^{4}$ Dee (2005) finds evidence that students who attended Catholic school in 10th grade were more likely to vote as adults, although he cannot exclude the possibility that this could reflect selection biases.

${ }^{5}$ The lack of focus of the World Bank on education in previous World Development Reports does not reflect a lack of interest in education in the past since education has traditionally be an important area of World Bank lending and grants to countries. But there is currently a renewed interest in education issues within the framework of the new Human Development Project launched in 2018.

${ }^{6}$ See http://www.worldbank.org/en/publication/wdr2018.

7 There are weaknesses in both pre-service and in-service training programs for teachers in many developing countries. While missionaries established many Teaching and Training Colleges, this function is to a large extent now managed by universities that are not necessarily Catholic.

${ }^{8}$ The World Bank provides estimates of harmonized learning outcomes for 157 countries as part of its Human Capital Index, but for some countries, estimates are based on somewhat old data. There are 193 countries in the world today (not including the Holy See and Palestine), suggesting that many countries, especially in the developing world, still do not have adequate measurement of learning outcomes.

${ }^{9}$ As noted in the World Development Report on the learning crisis (World Bank, 2018).

\section{Notes on Contributor}

Quentin Wodon is a Lead Economist with the Education Global Practice at the World Bank. His focus in the last two decades has been on policy analysis and dialogue in over 50 countries. He holds PhDs in Economics, Environmental Science, Health Sciences, and Theology and Religious Studies. Dr Wodon is also Distinguished Research Affiliate, Kellogg Institute, University of Notre Dame, Notre Dame, USA

\section{References}

Altonji, J. G., T. E. Elder, and C. R. Taber. 2005. An Evaluation of Instrumental Variable Strategies for Estimating the Effects of Catholic Schooling, Journal of Human Resources 40:791-821.

Backiny-Yetna, P., and Q. Wodon. 2009a. Comparing the private cost of education at public, private, and faith-Based schools in Cameroon. In Emerging Evidence on Vouchers and Faith-Based Providers in Education: Case Studies from Africa, Latin America, and Asia, edited by F. Barrera-Osorio, H. A. Patrinos, and Q. Wodon. Washington, DC: The World Bank. 
Backiny-Yetna, P., and Q. Wodon. 2009b. Comparing the performance of faith-based and government schools in the Democratic Republic of Congo. In Emerging Evidence on Vouchers and Faith-Based Providers in Education: Case Studies from Africa, Latin America, and Asia, edited by F. BarreraOsorio, H. A. Patrinos, and Q. Wodon. Washington, DC: The World Bank.

Banerjee, A. V., Cole, E. Duflo, and L. Linden. 2007. Remedying Education: Evidence from Two Randomized Experiments in India. Quarterly Journal of Economics, 122(3): 1235-64.

Bashir, S., M. Lockheed, E. Ninan, and J. P. Tan, 2018. Facing Forward: Schooling for Learning in Africa. Washington, DC: The World Bank.

Boyle, H. N., S. Z. Seebaway, I. Lansah, and A. Boukamhi. 2007. Islamic education sector study: Ghana. Baltimore: USAID.

Brinig, M. F. and N. S. Garnett. 2014. Lost Classroom, Lost Community: Catholic Schools' Importance in Urban America. Chicago: The University of Chicago Press.

Cabezas, V., J. I. Cuesta, and F. A. Gallego. 2011. Effects of short-term tutoring on cognitive and noncognitive skills: Evidence from a randomized evaluation in Chile. Mimeo. Boston: J-PAL.

Congregation for Catholic Education. 1977. The Catholic School. Vatican City: Libreria Editrice Vaticana.

Congregation for Catholic Education. 2017. Educating to Fraternal Humanism: Building a "Civilization of Love" 50 Years after Populorum Progressio. Vatican City: Libreria Editrice Vaticana.

Conn, K. 2014. Identifying Effective Education Interventions in Sub-Saharan Africa: A meta-analysis of rigorous impact evaluations. Mimeo. New York: Columbia University.

Crouch, L. and DeStefano, J. 2015. A Practical Approach to In-Country Systems Research. Mimeo. RTI International.

Day Ashley, L., C. Mcloughlin, M. Aslam, J. Engel, J. Wales, S. Rawal, R. Batley, G. Kingdon, S. Nicolai, and P. Rose. 2014. "The Role and Impact of Private Schools in Developing Countries: A Rigorous Review of the Evidence." EPPI-Centre Report No. 2206, Education Rigorous Literature Review commissioned by the U.K. Department for International Development (DFID), London.

Dee, T. S. 2005. The Effects of Catholic Schooling on Civic Participation, International Tax and Public Finance, 12 (5): 605-25.

Delfra, L. A., W. C. Mattison, S. D. McGraw, and T. S. Scully. 2018. Education in a Catholic Key, in W. H. James, editor, The Handbook of Christian Education, New Jersey: Wiley Blackwell.

Duflo, E., P. Dupas, and M. Kremer. 2011. Peer Effects, Teacher Incentives, and the Impact of Tracking: Evidence from a Randomized Evaluation in Kenya. American Economic Review, 101(5): 1739-74.

Duflo, E., R. Hanna, and S. P. Ryan. 2012. Incentives Work: Getting Teachers to Come to School. The American Economic Review, 102(4): 1241-1278.

Elder, T., and C. Jepsen. 2014. Are Catholic Primary Schools More Effective than Public Primary Schools? Journal of Urban Economics, 80, 28-38.

Evans, D. and Popova, A. 2015. What Really Works to Improve Learning in Developing Countries? An Analysis of Divergent Findings in Systematic Reviews, Policy Research Working Paper No. 7203, Washington, DC: The World Bank.

Evans, D. and Popova, A. 2016. What Really Works to Improve Learning in Developing Countries? An Analysis of Divergent Findings in Systematic Reviews, World Bank Research Observer, 31: 242-70.

Evans, W., and R. Schwab. 1995. Finishing High School and Starting College: Do Catholic Schools Make a Difference? Quarterly Journal of Economics, 110:941-74.

Gemignani, R., M. Sojo, and Q. Wodon. 2014. What Drives the Choice of Faith-inspired Schools by Households? Qualitative Evidence from Two African Countries, Review of Faith \& International Affairs, 2014, 12(2): 66-76. 
Glewwe, P., N. Ilias, and M. Kermer. 2010. Teacher Incentives. American Economic Journal: Applied Economics (2): 205-27.

Glewwe, P. W., E. A. Hanushek, S. D. Humpage, and R. Ravina. 2014. School Resources and Educational Outcomes in Developing Countries: A Review of the Literature from 1990 to 2010. In P. Glewwe, editor. Education Policy in Developing Countries. Chicago and London: University of Chicago Press.

Grace, G. 2002a. Catholic Schools: Mission, Markets and Morality. London and New York: Routledge Falmer.

Grace, G. 2002b. Mission Integrity: Contemporary Challenges for Catholic School Leaders. In K. Leithwood and P. Hallinger, editors, Second International Handbook of Educational Leadership and Administration, Dordrecht: Kluwer Academic Press.

Hallaq, W. 2009. An Introduction to Islamic Law. Cambridge: Cambridge University Press.

He, F., L. Linden, and M. MacLeod. 2008. How to Teach English in India: Testing the Relative Productivity of Instruction Methods within the Pratham English Language Education Program. Mimeo. New York: Columbia University.

He, F., L. Linden, and M. MacLeod. 2009. A Better Way to Teach Children to Read? Evidence from a Randomized Controlled Trial. Cambridge, MA: Abdul Latif Jameel Poverty Action Lab.

Jepsen, C. 2003. The Effectiveness of Catholic Primary Schooling, Journal of Human Resources, 38:92841.

Lockheed, M., T. Prokic-Breuer, and A. Shadrova. 2015. The Experience of Middle-Income Countries Participating in PISA 2000-2015. Washington, DC: World Bank; Paris: OECD Publishing.

Kremer, M., C. Brannen, and R. Glennerster. 2013. The Challenge of Education and Learning in the Developing World. Science, 340(6130): 297-300.

Krishnaratne, S., White, H. and Carpenter, E. 2013. Quality education for all children? What works in education in developing countries. Working Paper No. 20. New Delhi: International Initiative for Impact Evaluation.

Lucas, A. M., P. J. McEwan, M. Ngware, and M. Oketch. 2014. Improving Early-Grade Literacy in East Africa: Experimental Evidence from Kenya and Uganda. Journal of Policy Analysis and Management, 33(4): 950-76.

McEwan, P. J. 2014. Improving Learning in Primary Schools of Developing Countries: A Meta-Analysis of Randomized Experiments. Review of Educational Research, 85(3): 353-94.

Moumne, R., and C. Saudemont. 2015. Overview of the Role of Private Providers in Education in Light of the Existing International Legal Framework: Investments in Private Education-Undermining or Contributing to the Full Development of the Human Right to Education?, UNESCO Working Papers on Education Policy No. 1. UNESCO, Paris.

Muralidharan, K. and V. Sundararaman. 2011. Teacher Performance Pay: Experimental Evidence from India, The Journal of Political Economy, 119: 39-77.

Murnane, R. J., and A. J. Ganimian. 2014. Improving Educational Outcomes in Developing Countries: Lessons from Rigorous Evaluations. NBER Working Paper No. 20284. Cambridge, MA: National Bureau of Economic Research.

Nayihouba, A., and Q. Wodon. 2018. Factors Affecting Student Performance in Primary Schools in West and Central Africa. Mimeo, Washington, DC: The World Bank.

Olivier, J., and Q. Wodon. 2014. Faith-inspired Education in Historical Perspective: A Case Study, Review of Faith \& International Affairs, 12(2): 27-37.

Parra Osorio, J. C., and Q. Wodon. 2014 Faith-Based Schools in Latin America: Case Studies on Fe y Alegría, Washington, DC: The World Bank.

Piper, B. and Korda, M. 2011. EGRA Plus: Liberia. Program Evaluation Report. RTI International. 
Secretaria Status, 2018. Statistical Yearbook of the Church 2016, Rome: Libreria Editrice Vaticana.

Wodon, Q. 2014. Education in sub-Saharan Africa: Comparing Faith-based, Private Secular, and Public Schools, Washington, DC: The World Bank.

Wodon, Q. 2015. The Economics of Faith-based Service Delivery: Education and Health in sub-Saharan Africa, New York: Palgrave Macmillan.

Wodon, Q., 2016. What Matters Most for Equity and Inclusion in Education Systems: A Framework Paper, SABER Working Paper No. 10, Washington DC: The World Bank.

Wodon, Q., 2019a. Enrollment in K12 Catholic Schools: Global and Regional Trends. Educatio Catholica, forthcoming.

Wodon, Q., 2019b. How Well Do Catholic and Other Faith-based Schools Serve the Poor? A Study with Special Reference to Africa. Part I: Schooling, International Studies on Catholic Education. Forthcoming.

Wodon, Q., and Y. Ying. 2009. Literacy and Numeracy in Faith-Based and Government Schools in Sierra Leone. In F. Barrera-Osorio, H. A. Patinos, and Q. Wodon, editors, Emerging Evidence on Vouchers and Faith-Based Providers in Education: Case Studies from Africa, Latin America, and Asia, Washington, DC: The World Bank.

World Bank. 2003. World Development Report 2004: Making Services Work for Poor People. Washington, DC: The World Bank.

World Bank. 2018. World Development Report 2018: Learning to Realize Education's Promise. Washington, DC: The World Bank.

Table 1: Satisfaction Rates with Schools by Type of School and Quintiles, Sub-Saharan Africa (\%)

\begin{tabular}{lcccccc}
\hline & \multicolumn{5}{c}{ Welfare quintiles } & \multirow{2}{*}{ All } \\
\cline { 2 - 5 } & $\begin{array}{c}\text { Poorest } \\
\text { Quintile }\end{array}$ & $\begin{array}{c}\text { Second } \\
\text { quintile }\end{array}$ & $\begin{array}{c}\text { Third } \\
\text { Quintile }\end{array}$ & $\begin{array}{c}\text { Fourth } \\
\text { quintile }\end{array}$ & $\begin{array}{c}\text { Richest } \\
\text { quintile }\end{array}$ & \\
\cline { 2 - 5 } Public & 51.9 & 54.2 & 55.9 & 58.9 & 63.6 & 56.8 \\
Faith-based & 51.5 & 67.0 & 72.7 & 73.2 & 80.1 & 72.8 \\
Private secular & 67.8 & 66.5 & 72.1 & 80.6 & 87.3 & 81.6 \\
Total & 53.3 & 55.7 & 58.8 & 63.2 & 72.0 & 60.9 \\
& & \multicolumn{7}{c}{ Secondary schools } & & \\
Public & 59.6 & 59.9 & 60.4 & 58.8 & 63.4 & 60.8 \\
Faith-based & 47.3 & 61.3 & 75.7 & 72.3 & 79.9 & 75.6 \\
Private secular & 67.6 & 66.1 & 69.2 & 66.1 & 82.3 & 77.1 \\
Total & 59.8 & 60.0 & 62.0 & 60.7 & 68.9 & 63.6 \\
\hline
\end{tabular}

Source: Wodon (2014). Estimates based on national household surveys for six countries.

Table 2: Principal Reasons for School Choice, Burkina Faso and Ghana (\%)

\begin{tabular}{lcccccc}
\hline & \multicolumn{3}{c}{ Burkina Faso } & \multicolumn{3}{c}{ Ghana } \\
\cline { 2 - 7 } & $\begin{array}{r}\text { Islamic } \\
\text { schools }\end{array}$ & $\begin{array}{c}\text { Christian } \\
\text { schools }\end{array}$ & $\begin{array}{c}\text { Public } \\
\text { schools }\end{array}$ & $\begin{array}{c}\text { Islamic } \\
\text { schools }\end{array}$ & $\begin{array}{c}\text { Christian } \\
\text { schools }\end{array}$ & $\begin{array}{c}\text { Public } \\
\text { schools }\end{array}$ \\
\hline Location & 38.7 & 33.3 & 70.0 & 20.8 & 16.7 & 37.5 \\
Religious knowledge & 83.9 & 33.3 & - & 75.0 & 50.0 & 6.3 \\
Moral education & 35.5 & 36.7 & - & - & 29.2 & - \\
To learn Arabic & 29.0 & - & - & 37.5 & - & - \\
To learn French/English & 25.8 & - & 3.3 & 4.2 & - & - \\
Teacher quality and discipline & 12.9 & 46.7 & 10.0 & 4.2 & 33.3 & 25.0
\end{tabular}




\begin{tabular}{lcccccc}
\hline Academic performance & 25.8 & 76.7 & 46.7 & 4.2 & 16.7 & 25.0 \\
Child's future (good education, jobs) & 9.7 & 6.7 & 16.7 & 4.2 & 4.2 & - \\
Familiarity with this school & - & 6.7 & 13.3 & 16.7 & 16.7 & 18.8 \\
No or low school fees & - & - & 30.0 & 4.2 & - & 31.3 \\
\hline
\end{tabular}

Source: Adapted from Gemignani et al. (2014a).

Note: Multiple answers allowed.

Table 3: Comparison of Student Performance for Selected School Types in Francophone Africa

\begin{tabular}{lccc} 
& Public school & Faith-based school & Private secular school \\
\hline Mathematics & 495.2 & 518.9 & 589.5 \\
Reading & 495.5 & 528.1 & 605.1 \\
\hline
\end{tabular}

Source: Nayihouba and Wodon (2018) using PASEC data.

Table 4: Selected Interventions with Some Consensus on Effectiveness in the Literature Reviews

\begin{tabular}{|c|c|}
\hline Area of intervention & Specific interventions \\
\hline \multirow{3}{*}{$\begin{array}{l}\text { Pedagogical } \\
\text { interventions that } \\
\text { match teaching to } \\
\text { Individual student } \\
\text { learning levels }\end{array}$} & $\begin{array}{l}\text { 1. Assign students to separate classes based on initial ability so that teachers can focus } \\
\text { instruction at the level of learning of individual students (Duflo et al. 2011) [4 reviews] }\end{array}$ \\
\hline & $\begin{array}{l}\text { 2. Use mathematics software to help students learn at their own pace (Banerjee et al. } \\
\text { 2007) [5 reviews]; by contrast just distributing computers does not by itself lead to gains }\end{array}$ \\
\hline & $\begin{array}{l}\text { 3. Train teachers to use an initial reading assessment and then continually assess student } \\
\text { performance in Liberia (Piper \& Korda 2011) [ } 2 \text { reviews] }\end{array}$ \\
\hline \multirow{3}{*}{$\begin{array}{l}\text { Individualized and } \\
\text { repeated teacher } \\
\text { training associated a } \\
\text { specific method or } \\
\text { task }\end{array}$} & $\begin{array}{l}\text { 1. Train teachers and provide them with regular mentoring to implement early grade } \\
\text { reading instruction in local language (Lucas et al. 2014) [3 reviews] }\end{array}$ \\
\hline & $\begin{array}{l}\text { 2. Combine student reading groups with in-school supervisors to provide ongoing } \\
\text { guidance to group leaders (Cabezas et al. 2012) [ } 2 \text { reviews] }\end{array}$ \\
\hline & $\begin{array}{l}\text { 3. Help teachers learn to use storybooks and flash cards (He et al. 2009) [1 review]; by } \\
\text { contrast, similar programs introduced without teacher preparation tend to be less } \\
\text { effective (He et al. 2008) [ } 3 \text { reviews] }\end{array}$ \\
\hline \multirow[t]{2}{*}{$\begin{array}{l}\text { Accountability- } \\
\text { boosting } \\
\text { interventions }\end{array}$} & $\begin{array}{l}\text { 1. Provide teacher with incentives to be present in school (Duflo et al. 2012) [4 reviews] } \\
\text { and perform (Muralidharan \& Sundararaman 2011) [3 reviews]; but design the incentives } \\
\text { to improve learning while reducing the risk of strategic countervailing teacher responses } \\
\text { (Glewwe et al. 2010) [5 reviews] }\end{array}$ \\
\hline & $\begin{array}{l}\text { 2. Supplement civil service teachers with locally hired teachers on short term contracts } \\
\text { (Duflo et al. 2012) [4 reviews], (Banerjee et al. 2007) [5 reviews] }\end{array}$ \\
\hline
\end{tabular}

Source: Wodon (2016), based on Evans and Popova (2015, 2016).

Table 5: Difference in the Average Impact of Broad-based and Focused Reforms/Interventions

\begin{tabular}{|c|c|}
\hline Magnitude of impacts & Examples of Reforms \\
\hline \multirow{3}{*}{$\begin{array}{l}\text { Broad-based reforms and } \\
\text { interventions with limited } \\
\text { impacts in the short run }\end{array}$} & $\begin{array}{l}\text { Structural reforms: public/private provision, decentralization, school autonomy, } \\
\text { results-based teacher pay, school-based management }\end{array}$ \\
\hline & Accountability and incentives, including local voice and choice \\
\hline & More inputs, whether for infrastructure or monetary incentives \\
\hline $\begin{array}{l}\text { Focused reforms and } \\
\text { interventions with large } \\
\text { impacts in the short run }\end{array}$ & $\begin{array}{l}\text { Pedagogical practices: improved teaching methods that meet the children where } \\
\text { they are, vastly improved textbooks based on rigorous research, use of the } \\
\text { children's mother tongue, and combinations of the various options }\end{array}$ \\
\hline
\end{tabular}


Source: Wodon (2016), based on Crouch and DeStefano (2015). 